\title{
(A)Political administration? The public manager's portrait and selection factors
}

\section{David Ferraz 12}

1 Instituto Universitário de Lisboa ISCTE-IUL / School of Sociology and Public Policy, Lisbon - Portugal

2 Universidade de Lisboa / ISCSP-UL - Institute of Social and Political Sciences, CAAP, Lisbon - Portugal

This article addresses the issue of how political and administrative actors relate to each other, focusing on the selection of Senior Civil Servants as key actors to implement public policies. A literature review and documental analysis were carried out, and an on-line questionnaire was applied to Senior Civil Servants in managerial positions in Portugal between 2004 and $2011(\mathrm{n}=964)$. The results show that, in all cases, the $p$-value was equal or less than .05 ( $\mathrm{p} \leq .05)$. The analysis allowed us to confirm two main criteria used for the selection of Senior Civil Servants (political and professional) and their respective factors. Despite indicating that the political criterion somehow plays a role in the selection of public officials in Portugal, the study could not confirm the hypothesis that political factors are predominant when hiring senior civil servants in the country.

Keywords: dichotomy; policy; administration; professionalization; politicization.

\section{Administração (a)política? 0 retrato e os fatores de seleção do dirigente público}

Este artigo centra-se na problemática sobre como os atores políticos e administrativos se relacionam, concentrandose na seleção de altos funcionários públicos como peças-chave no processo de implementação de políticas públicas. Em relação à metodologia adotada, foram realizadas uma revisão da literatura e uma análise documental, bem como a aplicação de um questionário on-line para altos funcionários que ocupavam cargos gerenciais entre 2004 e 2011 ( $\mathrm{n}=964)$. Em todas as análises, foram considerados estatisticamente significativos os resultados dos testes de hipóteses, com um valor de $p$ igual ou inferior a .05 ( $\mathrm{p} \leq .05$ ). A análise permitiu confirmar dois componentes/ critérios principais que estão na fonte da seleção de altos funcionários públicos (políticos e profissionais) e, dentro de cada um, os respetivos fatores que os compõem. Pudemos reconhecer que o componente político tem seu peso, mas não foi possível confirmar completamente a hipótese de que, em Portugal, os fatores que influenciaram a seleção de altos funcionários públicos eram predominantemente políticos.

Palavras-chave: dicotomia; política; administração; profissionalização; politização.

\section{¿Administración (a)política? El retrato y los factores de selección del dirigente público}

Este documento respalda la problemática acerca de cómo los actores políticos y administrativos se relacionan, enfocando particularmente la selección de altos funcionarios públicos como clave en el proceso de implementación de políticas públicas. Con respecto a la metodología utilizada, se realizaron una revisión de la literatura y un análisis documental, así como la aplicación de un cuestionario online a altos funcionarios que ocuparon cargos gerenciales entre 2004 y 2011 ( $\mathrm{n}=964)$. En todos los análisis se consideraron estadísticamente relevantes los resultados de dos pruebas de hipótesis con un valor de $p$ igual o inferior a $.05(\mathrm{p} \leq .05)$. El análisis permitió confirmar dos componentes/criterios principales que están en la fuente de la selección de altos funcionarios públicos (políticos y profesionales) y, dentro de cada uno, los respectivos factores que los componen. Pudimos reconocer que el componente político tiene su peso, pero no fue posible confirmar completamente la hipótesis de que, en Portugal, los factores que influyeron en la selección de los altos funcionarios públicos fueron principalmente políticos.

Palabras clave: dicotomía; política; administración; profesionalización; politización. 


\section{INTRODUCTION}

The political-administrative dichotomy is one of the themes of the science of Administration (but not the only one) to which many authors have dedicated special attention over the years. It has become, especially since Woodrow Wilson, one of the fundamental and structural issues in the relationship between politics and administration, influencing the way in which public policies are implemented. The causes are on one hand, organizational configurations which permit the separation/integration between politics and administration, and on the other, the relationships which are established between political and administrative actors. This is one of the crucial issues which contemporary democracies debate, and it is related to the interaction between political and administrative actors (Kernaghan, 2000 as cited in Peters, 1987; Neuhold, Vanhoonacker, \& Verhey, 2013; Sherman, 1998).

Within this setting, we will seek to deepen our knowledge of the selection of public managers within the context of the evolution of models of the state and administration, as well as better understand the relationships which are established in the definition and implementation of public policies between administrative and political actors in Portugal, characterizing, in particular, the population of public administration leaders and the selection of Portuguese public administration leaders, dividing this population into top public servants and senior managers in the terms of the Portuguese Leadership Personnel Statute, and we will also explore coordinating positions.

To accomplish this, the following hypotheses will be advanced:

1) In Portugal between 2004 and 2011, the factors which influenced the selection of top public servants were predominantly political.

2) In Portugal between 2004 and 2011, the factors which influenced the selection of senior managers were predominantly technical.

3) In Portugal between 2004 and 2011, the factors which influenced the selection of public administration leaders were distinct depending on whether we are dealing with top public servants or senior managers.

These hypotheses will be put into perspective by a review of the literature in relation to the problem of the separation/convergence between politics and administration. Later after putting these into perspective there will be an analysis based on a survey $(n=964)$ of the factors which most contribute to the selection of public administration leaders in Portugal, using as our main statistical analysis technique Principal Component Analysis. Based on the answers received from the respondents, this population will also be characterized from the demographic and professional points of view through descriptive statistics.

Finally, the main conclusions will be presented, discussing the results in view of the literature review, making it possible to analyze and discuss this classic problem of separation between politics and administration in Portugal.

\section{POLITICS AND ADMINISTRATION: SEPARATION OR CONVERGENCE?}

The problem of the separation between politics and administration, present in their respective dichotomy, is an issue that has been studied for various centuries and was present at the dawn of public administration, or the science of administration, as a discipline. The importance of studying this relationship comes from the fact that public administration is the determinant structure in the 
governance process, constituting a fundamental element in the configuration and architecture of the state. The political-administrative dichotomy is one of the oldest issues in the scientific study of public administration. Despite the great quantity of material that has been written on this subject, its discussion remains current, considering that a total separation between politics and administration is impractical or even undesirable.

The issue that we are considering, at least since the $19^{\text {th }}$ century, has to do with the balance of power and the relationship between political and administrative actors needed to optimize the results for society. The first attempts of a practical nature to separate administration from politics date from 1854 in the United Kingdom in which a report described the situation at the time: "The existing system is supported by long usage and powerful interests" (Northcote Trevelyan Report, 1854). In 1860, the introduction of the merit system began to be debated. Two decades later in January 1883 in the United States, the Pendleton Act was published, a federal law which founded the Civil Service Commission.

This act marked the adoption of a merit system instead of the existing spoils system, characterized as corrupt and discretionary. The idea to end the patronage system was to create a career in public administration which would be characterized by (Eymeri, 2001): permanence (life-long employment); unity and uniformity, with the recruitment of the best and self-guided careers, anonymity, and political neutrality.

Despite the enthusiasm with which this issue arose and was expanded over the following decades, the process of the professionalization of administration was morose (Ferraz, 2008a). In 1904, for example, only half of the employees of the United States federal administration had been recruited based on the merit system (Peters, 1996).

From the theoretical point of view, another important landmark was the automation of administration relative to politics, which was fundamental to the affirmation of the merit system, published in a book by Wilson in 1887 called The Study of Administration (Rocha, 2009). He argued for a rigorous separation between politics and administration so that the spoils system would be completely eliminated and scientific administration would emerge. Goodnow and Weber made further contributions. The former reinforced the idea that characterized the model idealized by Wilson, highlighting the theoretical level, namely the boundaries between political and administrative functions. The latter confirmed this distinction, turning the administrative model into a hierarchically organized bureaucracy (Rocha, 2000).

Weber's contribution was based essentially on the statute of bureaucracy as an organized means to legal, economic and technical rationality. Weber believed that organizations which were organized according to bureaucratic principles would be superior to others (Rocha, 2000). Rationality and the technical domain were therefore incompatible in this conception with a highly politicized system, thus affirming a merit-based model. This would also be a way to limit arbitrary and absolute power - in line with the double subordination of administration - not just in relation to political power but the legal power of the state as well.

He believed that employees with technical knowledge should serve not only the political class but also the public interest. The implementation of politics would thus be exempt from partisan issues and employees would act in accordance with the rights and duties established by the specific employee statute - known as a public servant and not one of the crown, demonstrating the transition from the absolutist state to the rule of law. 
In this model, administration is strongly conditioned by the law, and its domain of activity is very well delineated and rests on a formally hierarchical command and control structure. Simple and routine work processes, the fruit of an elevated division of labor, were standardized by laws, rules, regulations and formal procedures. The leadership structure reserved decision-making power for itself. Decisions were thus strongly centralized with the objective of controlling all actions within a stable environment and context. The Public Servant Statute, with "employment for life", sought to protect citizens from political arbitrariness, the opposite of what people normally judge these days.

In addition, the statute envisioned, to incorporate the safeguards of the rule of law in administration, an automatic progression in bureaucratic careers in order not to suffer political-partisan subversions of the public interest. An above average remuneration regime compared to the private sector sought on one hand to attract and maintain the best employees in the administration, and on the other to confer on the administrative employee (to the citizens' benefit) neutrality, impartiality, independence and subjugation to the law, even in the face of illegal political guidance, avoiding their corruption and ensuring that they remained faithful to the rule of law.

The tendency was in this context to separate politics and administration relying, as Chevallier mentions (2002), on a fundamental postulate: the political actor has the power of command [...] and the administration, through the intermediation of its employees, executes it. This separation should be absolute and there are no great doubts in regard to the different roles of administration and politics (Kellner, 1981):

1) The administration exists to assist politicians in their decisions and their concretization.

2) The elected political power is held responsible by congress for the public policies that it formulates.

Without prejudice in regard to the evolution of the patronage and spoils system to a more professional system in which administrative activities were better differentiated from political activities, the line of separation between these activities continued to be somewhat unclear, and thus the political-administrative dichotomy is debatable. The reasons that justify this situation are based on the intrinsically political nature of administration (Stillman, 1997; Waldo, 1948 as cited in Chevallier, 2002): public management is more a product of professional and institutional context than a product of a forecast of a group of fixed norms (Kickert, 2005 as cited in Peters \& Pierre, 2004).

If traditionally the total separation between politics and administration was argued for, based on Wilson's dichotomy (Cope, Leishman, \& Starie, 1997), today, more and more authors (Aberbach, 1988; Aberbach, Putnam, \& Rockman, 1981; Dowding, 1995; Ferraz, 2008b; Giauque, Resenterra, \& Siggen, 2009; Kellner, 1981; Mulgan, 2007; Peters, 1986) are finding close links between the political and administrative spheres. This is due, in large part, to a lack of faith in the traditional bureaucratic model. In this way, this has led to difficulty and even failure in creating a bureaucratic administrative system (Ferraz, 2008b; Giauque et al., 2009; Mulgan, 2007) based on the separation between politics and administration. As a result, the neutrality and independence of administration has been questioned in relation to political power.

Despite the fact that theoretically this has been the dominant system for many years and has contributed to the reduction of systems based on favoritism, the truth is that in practice the total separation between politics and administration has always been questioned (Catlaw \& Hu, 2009; Chevallier, 2002; Leon \& Vogenbeck, 2007; Downs, 1978; Ferraz, 2008b; Peters, 2001a; Peters \& Pierre, 2004; Stillman, 1997). 
Downs (1978 as cited in Rocha, 2005a) goes further and contests the separation between politics and administration as a reality. To him, bureaucrats cannot be considered to be machines because they have their own interests. Mozzicafreddo (2001) also argues that power does not only flow from the top of the hierarchy: there exist spaces of power and autonomy in the intermediate levels and the base of the organizational structure in terms of the application of procedures and the interpretation of directives from the top. Mozzicafreddo (2001) suggests that today the idea of a disinterested public administration which relies only on impartiality and the universality of measures is neither very evident or peaceful. All spaces of power present in the administrative level, which have the capacity to influence decisions, come from specific technical knowledge, which is essential to the bureaucratic process of governance and has progressively gained a certain autonomy coming to be recognized for having more knowledge about certain political issues that the politicians themselves (Peters, 1987). For this reason, models and theories generally recognize that these public servants are powerful figures (Dowding, 1995), influencing public organizational structures as pointed out by Mintzberg (1995).

This assumption contradicts the total separation between politics and administration. Kellner (1981) even emphasizes that due to the lack of technical knowledge on the part of politicians, it is inevitable that public servants have greater power and influence than democratic theories grant them. The phrase of the 1970s - "Officials propose, ministers dispose, officials execute [...] civil servants are our servants” (Kellner, 1981, p. 203) - is far removed from a simple process of governance. Dowding (1995) says that, as political advisors, public servants directly influence the formulation of policies, which confers on them a political connotation and a formulation activity, rather than passive activity subordinated to application or implementation. He adds that bureaucrats are constant, stable and permanent, and possess technocratic knowledge which gives them informal power, capable of limiting the actions of the government.

Public Choice Theory is perhaps what has most stimulated interest in knowledge of the interactions between politics and administration over the past few decades. The theory, defended by Downs (1967 as cited in Rocha, 2005b) in the book Inside Bureaucracy, categorizes various types of bureaucracy in terms of their behavior, affirming that they are not neutral and depend on the bureaucrat's intentions.

This entire context provides a continuum of functions that turn the boundary between politics and administration into a mix of roles that makes it difficult to identify a line of separation between politics and administration and to attribute differentiated roles and responsibilities between them.

This demonstrates the difficulty of implementing a neutral bureaucratic structure independent of political power as Weber envisioned in his conception of the model of bureaucratic structure. Dowding (1995) adds that in fact it does not appear possible to state and guarantee that an administration is politically neutral, given that ministers always wish for partiality in the selection of their collaborators.

In general, authors recognize that it is difficult to make a total separation between politics and administration. Peters (2001a) states that it is historical-cultural dynamism and the configuration of decision making (more or less fragmented) which establishes the boundary between politics and administration. Within this dynamism, New Public Management has been associated with a large variety of interventions, paths and intensities in terms of reform (Hood \& Lodge, 2006).

This model for organizing the state and administration, which has spread all over the western world like a trend (Carvalho, 2008b), has motivated many academic discussions. The reforms implemented based on New Public Management, in particular during the Thatcher and Reagan administrations in the 
United Kingdom and the United States (Cohen \& Eimicke, 2011), sought to use market mechanisms as an alternative to the traditional providing of goods and services to the population, based on theories and assumptions of economic rationality, whose origins were based on public choice theory and its disciples (Denhardt \& Denhardt, 2007; Moreira \& Alves, 2010), and the assumption that public organizations were dominated by the interests of "producers of public services" (Stoker, 2006).

The objective was to improve the provision of public services, constructing new forms of partnership between state and non-state organizations as well as new types of regulation and responsibility (Pitschas, 2003), seeking to dismantle the bureaucratic pillar of traditional public administration (Stoker, 2006).

The model was proposed as an alternative based on the belief that business management was superior to public administration leading to the term New Public Management, in which all administrative activities and services which were not central to the state could be outsourced and provided by the private sector (Moreira \& Alves, 2010), which was the classic formulation of New Public Management (Hood \& Jackson, 1991).

Given this context, during the 1980s there was a movement that embraced these principles and attracted a vast number of countries within the Organization for Economic Cooperation and Development (OECD), including Portugal. This is signaled by the fact that during the period (2002-2010), three administrations took power, with the reform beginning with the Resolutions $n^{\circ}$ 95/2003 and 53/2004 of the Council of Ministers, and its objectives were maintained in general during each of these three administrations independent of their political party bias. The period was marked by a strong expansion of New Public Management, which dictated a reorganization of the state and administration, with a great emphasis on an entrepreneurial makeover, a new philosophy for human resources, the introduction of market mechanisms in administration, a tendency towards outsourcing and the centralization of services to attain economies of scale, creating shared service entities (GERAP and ANCP).

These matters, and now in the next section we will analyze how the new reform influenced the selection factors for public managers in Portugal.

\section{FACTORS WHICH CONTRIBUTE TO THE SELECTION OF PUBLIC ADMINISTRATION LEADERS IN PORTUGAL}

To better understand the selection of public administration leaders in Portugal, it is important to first identify the typology of leadership positions based on the current personnel statute in Portugal. The law distinguishes two levels - which could be more if the organization statutes foresaw this - each with two grades as the OECD recommends: ${ }^{1}$

\section{Level 1 - Top Public Servants}

$1^{\text {st }}$ grade - director general, secretary general, inspector general or president.

$2^{\text {nd }}$ grade: sub-director general, deputy secretary general, sub-inspector general, vice-president and board members.

\footnotetext{
${ }^{1}$ The previous statutes for leadership personnel also used this distinction. It is not, therefore, an innovation of the new statute. Even so, it is important to demonstrate that the law continues to make this distinction.
} 


\section{Level 2 - Senior Management}

$1^{\text {st }}$ grade - service manager

$2^{\text {nd }}$ grade - division head

The constitution of this study is based on the typology of the positions explained above. With the constituted database $(n=964)$, the data was selected using the Principal Component Method, and analyzing the correlation matrix, with a maximum of 25 interactions by convergence. The Varimax rotation was also used, which is a method of orthogonal rotation proposed by Kaiser (1958). It proposes that "for each rotation of factors that occurs, high positions appear with few variables, while the other positions remain close to zero" (Mager, 1973). To determine the appropriateness of the data analysis, we used the Kaiser-Meyer-Olkin (KMO) statistic which compares correlations among variables, that is, it indicates the proportion of data variance that can be attributed to a common factor, and it varies between 0 and 1 .

To evaluate the fit of the sample in the application of factor analysis, the information in the Box below was used.

\begin{tabular}{cc|}
\hline KMO & Fit of the factor analysis \\
\hline $1-0.9$ & Very good \\
$0.8-0.9$ & Good \\
$0.7-0.8$ & Average \\
$0.6-0.7$ & Reasonable \\
$0.5-0.6$ & Bad \\
$>0.5$ & Unacceptable \\
\hline
\end{tabular}

Source: Elaborated by the author.

The development of this step involved using Version 23 of the SPSS application and following the steps below:

1) Analyze the anti-image correlation matrix, the sphericity test, and the KMO measurement, to identify whether they are appropriate for this analysis.

2) Extract the rotation factors using the Varimax method in order to facilitate their interpretation.

3) Interpret the factors and analyze the obtained scores.

4) Validate the model. 


\section{TOP PUBLIC SERVANTS: FACTORS WHICH INFLUENCED THEIR SELECTION FROM 2004 TO 2011}

Applying the referenced tests to the study sample, referenced in a footnote, this model obtained an explanation of $60.7 \%$ of the total variance in the selection of top public servants through the aggregation of 2 components in accordance with the tables and graphs below.

TABLE 1 TOTAL EXPLAINED VARIANCE (TOP PUBLIC SERVANTS)

\begin{tabular}{|c|c|c|c|c|c|c|}
\hline \multirow{2}{*}{ Component } & \multicolumn{3}{|c|}{ Their Initial Values } & \multicolumn{2}{|c|}{ Sums of Extraction Loads } & \multirow{2}{*}{ Cumulative $\%$} \\
\hline & Total & Variance $\%$ & Cumulative \% & Total & Variance $\%$ & \\
\hline 1 & 4.369 & 33.608 & 33.608 & 4.369 & 33.608 & 33.608 \\
\hline 2 & 3.528 & 27.141 & 60.749 & 3.528 & 27.141 & 60.749 \\
\hline 3 & 0.840 & 6.461 & 67.209 & & & \\
\hline 4 & 0.778 & 5.981 & 73.191 & & & \\
\hline 5 & 0.598 & 4.600 & 77.790 & & & \\
\hline 6 & 0.515 & 3.959 & 81.749 & & & \\
\hline 7 & 0.494 & 3.803 & 85.552 & & & \\
\hline 8 & 0.435 & 3.350 & 88.902 & & & \\
\hline 9 & 0.387 & 2.979 & 91.881 & & & \\
\hline 10 & 0.350 & 2.692 & 94.573 & & & \\
\hline 11 & 0.333 & 2.562 & 97.135 & & & \\
\hline 12 & 0.290 & 2.231 & 99.365 & & & \\
\hline 13 & 0.083 & 0.635 & 100.000 & & & \\
\hline
\end{tabular}

Extraction method: Principal component analysis.

Source: Elaborated by the author.

The graph below verifies the existence of an inflection point for Factor 3, from which using the scree plot criterion, which indicates that the number of factors to be extracted corresponds to the number of factors to the left of the inflection point (Cattell, 1966), or in other words, 2. 


\section{GRAPH 1 FACTOR ANALYSIS (TOP PUBLIC SERVANTS)}

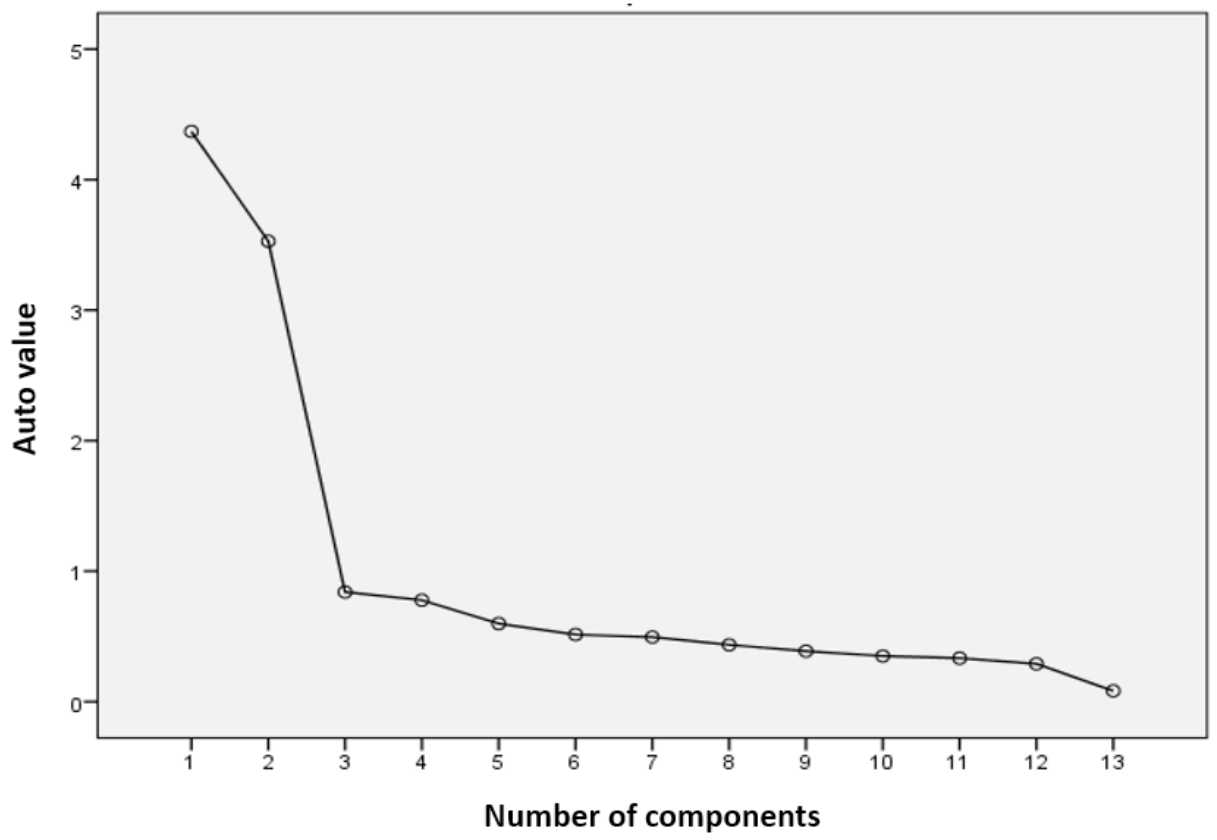

Source: Elaborated by the author.

The table below presents the factor loading after the rotation, which makes it possible to identify the component matrix.

\section{TABLE 2 FACTORS WHICH INFLUENCE THE SELECTION OF TOP PUBLIC SERVANTS COMPONENT MATRIX} (TOP PUBLIC SERVANTS)

\begin{tabular}{lcc} 
& \multicolumn{1}{c}{ Components } \\
Component Matrix (a) & 1 & 2 \\
(Professional) & (Political) \\
Knowledge from area of education/specialization & 0.818 \\
Previous experience in public administration & 0.800 \\
Performed similar functions before as a technical specialist in the same area & 0.798 \\
Behavioral skills of the person & 0.794 \\
Skills envisaged in the leadership personnel statute demonstrated in front of a competition & 0.785 \\
jury or a leader before the nomination & \\
Political exemption and neutrality & 0.709
\end{tabular}




\begin{tabular}{lcc} 
Component Matrix (a) & $\begin{array}{c}\text { Components } \\
\text { (Professional) }\end{array}$ & $\begin{array}{c}\text { (Political) } \\
\text { Regularly frequents key decision-making circles }\end{array}$ \\
$\begin{array}{l}\text { Political ideology } \\
\text { Party affiliation }\end{array}$ & -0.473 & 0.765 \\
Enjoys proximity to, and confidence of, another person & -0.531 & 0.745 \\
An economic and financial position above the national average & 0.697 \\
Shares the same strategic vision of the government's organization/program & 0.674 \\
Has access to valuable information regarding the leadership position and its functional content & 0.632 \\
\hline
\end{tabular}

Extraction method: Principal component analysis. a. 2 Extracted components.

Source: Elaborated by the author.

\section{SENIOR MANAGERS: FACTORS WHICH INFLUENCED THEIR SELECTION FROM 2004 TO 2011}

With the performed tests, this model explains $51.5 \%$ of the total variance in the selection of senior managers, with the aggregation of 2 components as can be seen in the tables and graphs below.

\section{TABLE $3 \quad$ TOTAL EXPLAINED VARIANCE (SENIOR MANAGERS)}

\begin{tabular}{|c|c|c|c|c|c|c|}
\hline \multirow[t]{2}{*}{ Component } & \multicolumn{3}{|c|}{ Their Initial Values } & \multicolumn{3}{|c|}{ Sums of Extraction Loads } \\
\hline & Total & Variance $\%$ & Cumulative $\%$ & Total & Variance $\%$ & Cumulative $\%$ \\
\hline 1 & 4.083 & 29.163 & 29.163 & 4.083 & 29.163 & 29.163 \\
\hline 2 & 3.138 & 22.413 & 51.576 & 3.138 & 22.413 & 51.576 \\
\hline 3 & 0.964 & 6.886 & 58.462 & & & \\
\hline 4 & 0.917 & 6.547 & 65.009 & & & \\
\hline 5 & 0.809 & 5.779 & 70.788 & & & \\
\hline 6 & 0.660 & 4.718 & 75.506 & & & \\
\hline 7 & 0.604 & 4.312 & 79.818 & & & \\
\hline 8 & 0.555 & 3.964 & 83.782 & & & \\
\hline 9 & 0.541 & 3.861 & 87.643 & & & \\
\hline 10 & 0.432 & 3.087 & 90.730 & & & \\
\hline 11 & 0.417 & 2.976 & 93.706 & & & \\
\hline 12 & 0.406 & 2.898 & 96.604 & & & \\
\hline 13 & 0.363 & 2.594 & 99.198 & & & \\
\hline 14 & 0.112 & 0.802 & 100.000 & & & \\
\hline
\end{tabular}

Extraction method: Principal component analysis.

Source: Elaborated by the author. 
The graph below verifies the existence of an inflection point for Factor 3, from which using the scree plot criterion (Cattell, 1966), we can see that the number of factors to be extracted corresponds to the number of factors to the left of the inflection point, or in other words, 2 .

\section{GRAPH 2 FACTOR ANALYSIS (SENIOR MANAGERS)}

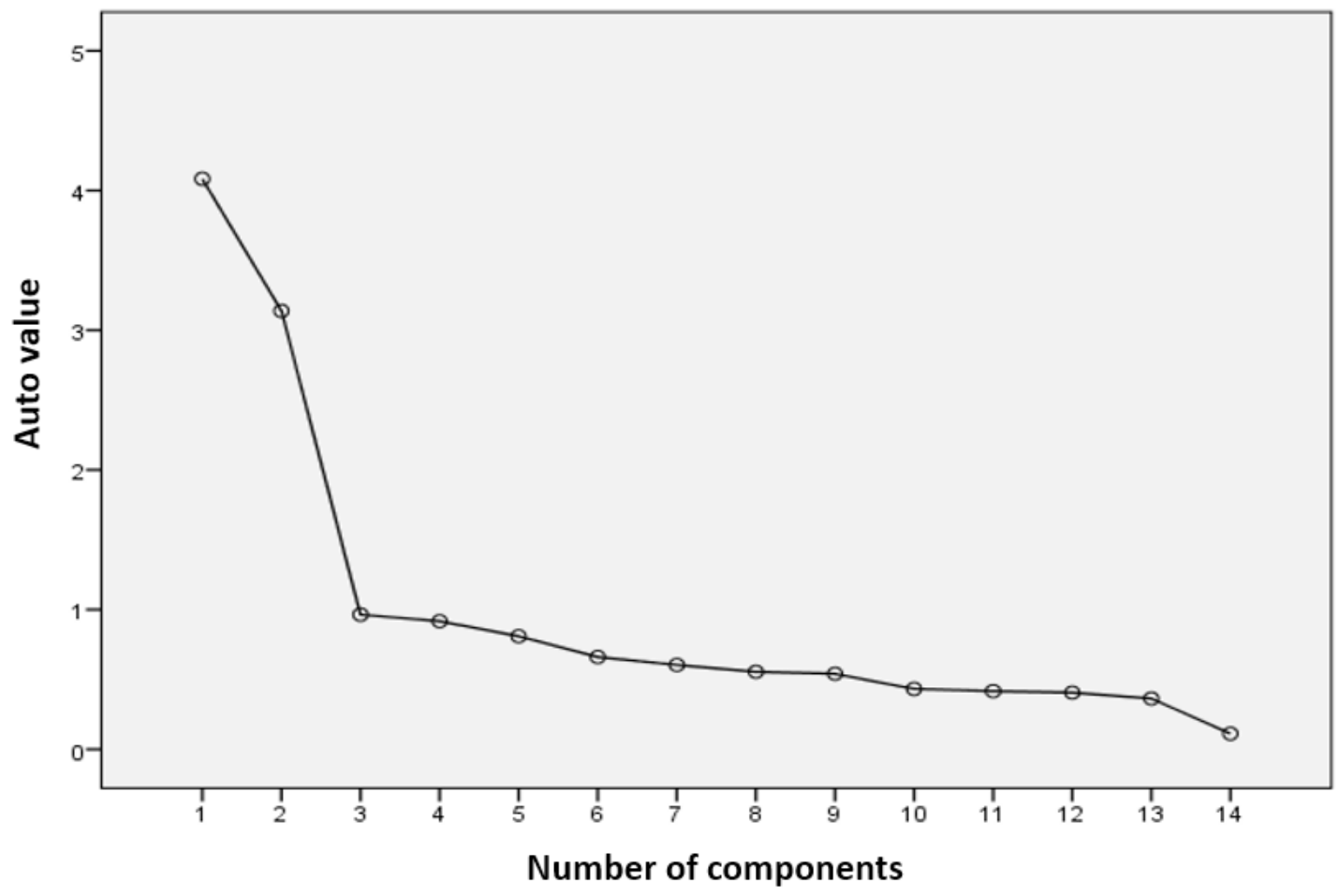

Source: Elaborated by the author.

The table below presents the factor loading after the rotation which makes it possible to identify the component matrix. 


\section{TABLE 4 COMPONENT MATRIX (SENIOR MANAGERS)}

\begin{tabular}{|c|c|c|}
\hline \multirow[t]{2}{*}{ Component matrix (a) } & \multicolumn{2}{|c|}{ Components } \\
\hline & $\begin{array}{c}1 \\
\text { (Professional) }\end{array}$ & $\begin{array}{c}2 \\
\text { (Political) }\end{array}$ \\
\hline Behavioral skills of the person & 0.798 & \\
\hline Knowledge from area of education/specialization & 0.771 & \\
\hline $\begin{array}{l}\text { Skills envisaged in the leadership personnel statute demonstrated in front of a competition jury or } \\
\text { a leader before the nomination }\end{array}$ & 0.708 & \\
\hline Previous experience in public administration & 0.706 & \\
\hline Performed similar functions before as a technical specialist in the same area & 0.686 & \\
\hline Political exemption and neutrality & 0.635 & \\
\hline Traditionally recognized schools or universities (in particular for exercising public functions) & 0.577 & \\
\hline Political ideology & -0.395 & 0.754 \\
\hline Regularly frequents key decision-making circles & & 0.749 \\
\hline Party affiliation & -0.469 & 0.731 \\
\hline An economic and financial position above the national average & & 0.692 \\
\hline Enjoys proximity to, and confidence of, another person & & 0.642 \\
\hline Has access to valuable information regarding the leadership position and its functional content & 0.381 & 0.528 \\
\hline Shares the same strategic vision of the government's organization/program & 0.346 & 0.511 \\
\hline
\end{tabular}

Extraction method: Principal component analysis. a. 2 components extracted.

Source: Elaborated by the author.

\section{THE PROFILE OF PORTUGUESE PUBLIC ADMINISTRATION LEADERS}

\subsection{Gender}

In terms of analyzing the sample by gender, an almost perfect distribution of leadership positions can be verified (50.2\% male as opposed to $49.8 \%$ female). Even though the differences are not particularly relevant, the higher the position, the greater the proportion of leaders of the male gender. 
TABLE 5 SURVEYED LEADERS BY GENDER

\begin{tabular}{rlcccc} 
& & Senior Managers & $\begin{array}{c}\text { Top Public } \\
\text { Servants }\end{array}$ & $\begin{array}{c}\text { Coordinators not integrated } \\
\text { in the LPS }\end{array}$ & Total \\
\hline \multirow{2}{*}{ q 0001} & Male & $38.8 \%$ & $8.5 \%$ & $2.9 \%$ & $50.2 \%$ \\
& Female & $40.9 \%$ & $6.4 \%$ & $2.5 \%$ & $49.8 \%$ \\
Total & & $79.7 \%$ & $14.9 \%$ & $5.4 \%$ & $100.0 \%$ \\
\hline
\end{tabular}

Source: Elaborated by the author.

\subsection{Age}

In respect to age, $59.2 \%$ of the leaders are more than 46 years old. The 36 to 45 age group represents $35.3 \%$, and the younger than 36 group represents 5.5\% (Table 6). The average age of leaders, taking into consideration that they are presented in classes of different sizes, was calculated by the resource that identifies the center of the class. In this manner, it was possible to verify that the average age of Portuguese public administration leaders is roughly 48 years of age. If we consider just the top public servants, the average age is approximately 50 years of age, while the average age of the senior managers is roughly 47 years of age.

\section{TABLE 6 AGE OF SURVEYED LEADERS}

\begin{tabular}{|c|c|c|c|c|}
\hline Age & $\begin{array}{l}\text { Coordinators not integrated in } \\
\text { the LPS }\end{array}$ & Senior Managers & $\begin{array}{l}\text { Top Public } \\
\text { Servants }\end{array}$ & Total \\
\hline Over 65 & & $0.20 \%$ & $0.40 \%$ & $0.60 \%$ \\
\hline 61 to 65 & $0.10 \%$ & $1.80 \%$ & $0.90 \%$ & $2.80 \%$ \\
\hline 56 to 60 & $0.70 \%$ & $10.60 \%$ & $3.20 \%$ & $14.50 \%$ \\
\hline 46 to 55 & $2.40 \%$ & $33.40 \%$ & $5.50 \%$ & $41.30 \%$ \\
\hline 36 to 45 & $1.70 \%$ & $29.00 \%$ & $4.60 \%$ & $35.30 \%$ \\
\hline 31 to 35 & $0.40 \%$ & $4.30 \%$ & $0.30 \%$ & $5.00 \%$ \\
\hline 20 to 30 & $0.10 \%$ & $0.40 \%$ & & $0.50 \%$ \\
\hline Total & $5.40 \%$ & $79.70 \%$ & $14.90 \%$ & $100.00 \%$ \\
\hline
\end{tabular}

Source: Elaborated by the author.

\subsection{Origin}

In terms of the origin of the leaders, most are from Lisbon (31.10\%). The second district with the most leaders is Porto (10.4\%). It also should be noted that there is a relatively elevated representation - the third largest origin of these leaders - from Portuguese speaking African countries, which may be due to recent decolonization - and among them, just $4.82 \%$ are less than 35 years of age. 


\subsection{Education}

In terms of degrees, even though the Leadership Personnel Statute (LPS) requires them for leadership positions, 20 of the respondents did not have a degree (approximately $2 \%$ ).

In terms of the number of leaders with higher degrees, such as Masters or PhDs, they represented 18.46\%, with PhDs representing just 2.8\%. In terms of their area of concentration, the following were the most representative in decreasing order, not including the "other area" category:

1) Law;

2) Public Administration/Management;

3) Economics;

4) Management;

5) Exact Sciences.

\section{GRAPH 3 DEGREE CONCENTRATIONS OF THE SURVEYED LEADERS}

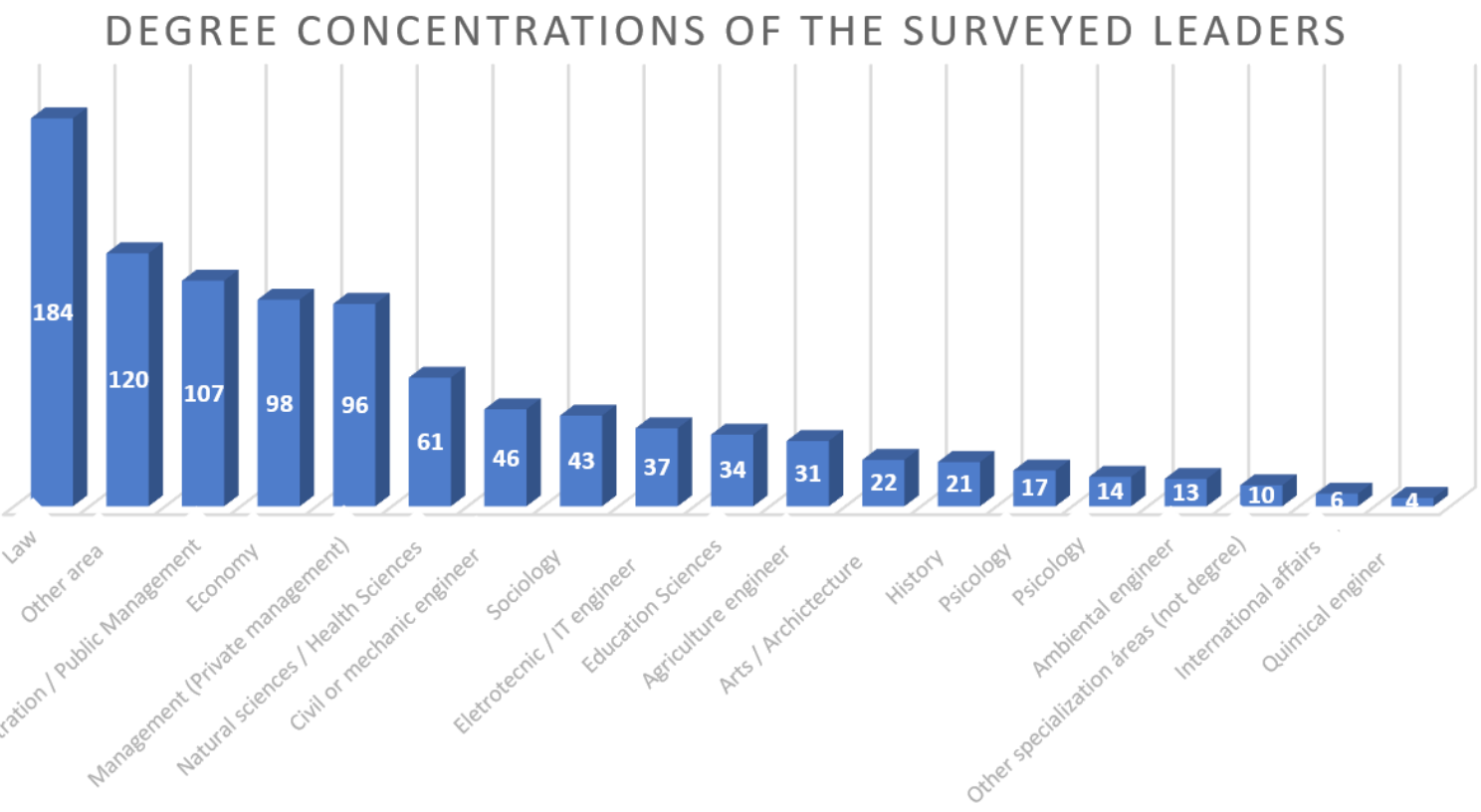

Source: Elaborated by the author.

\subsection{Family: Leader Relatives}

One of the characteristics most mentioned in relation to patronage (Flinders, 2009; Montjoy \& Watson, $1995)$ is the distribution of administrative positions to relatives or people close to current occupants. Most of the leaders had no relatives working in administration (64.42\%); 31.95\% stated that they had ancestors working in administration; $2.80 \%$ descendants; and $0.83 \%$ ancestors and descendants.

Curiously, the higher the leadership position, the lower the percentage of ancestors who worked in the administration in the past. This relationship did not hold true in cases in which leaders had 
descendants in the administration. Among these, only $27.28 \%$ stated that relatives did not have leadership functions or political positions. We may note, however, a high percentage of respondents who preferred not to answer the question (62.66\%). Among those who responded, the majority performed a leadership position in public administration (8.71\%), and only $1.5 \%$ occupied a political position. Approximately $10 \%$ state that they had or have an ancestor or descendant performing leadership functions in administration or political positions. The distribution of the responses did not change in relation to different positions.

One of the most used indicators in studies characterizing public leaders is the qualification of the ancestors. In the sample, of the 964 respondents, only 216 had among their direct ancestors' parents with license degrees. The breakdown of the data for the higher degrees of their ancestors, separated by education area and type of position held, demonstrate that the 3 most common, not considering the non-categorized areas, were:

\section{Senior Managers}

1. Exact or natural sciences/Health

2. Education sciences

3. Civil or mechanical engineering

\section{Top Public Servants}

1. Education sciences

2. Civil or mechanical engineering

3. Law

\subsection{Experience in the private sector}

A very significant portion of the leaders (top public servants and senior managers) do not have experience in the private sector (54.05\%) and began their professional career in public administration. There were $40.35 \%$ with private sector experience of less than 10 years. There were only $5.6 \%$ with more than 10 years of private sector experience. Among these, those who are top public servants are the majority (8.33\%), followed by senior managers (5.21\%) and non-LPS coordination positions $(3.84 \%)$.

If we consider just leadership functions in the private sector, $78.63 \%$ of the administrative leaders never held these positions. Those who have up to 10 years of experience in the private sector represent $15 \%$ of the leaders, with top public servants having greater representation (19.44\%) compared to senior managers (14.71\%). With over 10 years of private sector experience the leadership experience is identical, with the top public servants having the greatest representation (7.64\%) compared to senior managers (5.34\%).

\subsection{Experience in the public sector: career, seniority and leadership positions}

Only $1.2 \%$ (top public servants) and $0.8 \%$ (senior managers), among all the respondents did not have any ties to public administration. This is explained by the fact that only people with ties to administration could exercise the functions of senior managers - except that at some points in time there were not an enough applicants. 
Only $12.4 \%$ of senior managers have less than 10 years in the public sector. The great majority have more than 11 years in administration (87.7\%). It is interesting to know which careers those working in public administration had before. Among the respondents, $4.10 \%$ had no ties to administration. Among those with ties to administration, most (69.30\%) began as upper level technical specialists, and $25.8 \%$ in special careers. Those with careers which did not require license degrees represent $0.7 \%$, and these are mainly coordinators who are not integrated in the LPS.

More than half of the respondents have less than 8 years of experience in leadership positions, and $45 \%$ have 9 or more years. Only $1 \%$ have more than 30 years of experience and the percentage of those with 16 to 30 years of experience is $14.4 \%$.

Among the respondents who had more leadership functions, we find the top public servants (18\% had 5 or more positions), while senior managers and coordinators represent respectively $7.68 \%$ and $5.76 \%$. The most common situation for senior managers is to have worked in two distinct positions (71.74\%). In the case of top public servants, 3 positions are needed to cover $50 \%$ of the group.

Taking into account the administrative structures in which the functions mentioned above occurred, most were in the Ministry of Labor and Social Solidarity; the Ministry of Science, Technology and Higher Education; and the Ministry of Finance and Public Administration. ${ }^{2}$

The number of responses was higher than the number of respondents on average because in many instances, leaders performed more than one position and this may have occurred in various administrative structures. Another interesting piece of data within the context of this study has to do with the number of renewals of service commissions in reference to the current position or the last position. Around one third of the senior managers and top public servants have never renewed their service commission and are in their first mandate. The tendency in terms of the number of renewals seems to be the same among the LPS positions, diminishing the number of leaders to the extent that the renewals increased.

Those with more than 2 renewals as top public servants, that is more than 9 years in the same position ( 3 or more renewals) represent $18.74 \%$ of the leaders. The percentage for those with 4 or more renewals in the same position (more than 12 years) decreases to $8.33 \%$, which demonstrates the relative stability of the exercise of some of the functions of top public servants.

Senior managers with 3 or more renewals, that is more than 9 years in the same position represent $22.13 \%$ of the leaders. However, if we consider the percentage of those who had 4 or more renewals in the same position (more than 12 years), the percentage decreases to $10.15 \%$, which demonstrates the relative stability in the exercise of some of the functions of senior managers.

The leadership functions with most stability - be they top public servants or senior managers - are found in the ministries corresponding to the social areas: Ministry of Science, Technology and Higher Learning (MCTES), Ministry of Labor and Social Solidarity (MTSS) and the Ministry of Health (MS).

The ministries which have the largest number of leaders in their first mandate are: MCTES, MTSS, Ministry of Agriculture, Rural Development and Fishing (MADRP) and the Ministry of Health. This

${ }^{2}$ Designation of the ministries when the survey was distributed. 
may be explained by the size of the ministry and the higher representation of respondents in these bodies. The appearance of the MADRP may be related to the substitution of leaders due to reforms associated with the Reform Program for the Central Administration of the State (PRACE).

\subsection{Professional training}

A relatively high number of leaders did not have any technical training relevant to the exercise of their leadership functions during the 5 years preceding the present study (17.5\%). If we add the number of non-responses and "do not know" responses to this, we reach a total of $27.9 \%$. This value is close to the number of leaders who are in the first mandate of their service commissions, allowing the leadership personnel statute to be fulfilled by the end of the first service commission, since this is a criterion just for renewal and not for the initial mandate.

Almost two thirds of the respondents (32.2\%) have more than 120 hours of relevant training realized during the past 5 years. The number of leaders who have had training envisioned by the LPS was greater after 2007, 3 years after they became mandatory.

\subsection{Turnover and cessation of functions}

The turnover of leaders is also a signal of frequent politicization. The data relative to service commission renewals for nominated leaders makes it possible to verify that $60.89 \%$ state that their commissions were always renewed. Almost 40\% (39.11\%) say that the commission was not always renewed.

Among those who affirm that the service commission was not always renewed, the majority (52.9\%) state that the reason was due to "structural alterations in the organization" (32.41\%) or the "acceptance of other public positions" (20.50\%). Even though $54.85 \%$ of the leaders assume that the non-renewal of their commission was due to exogenous factors, $42.15 \%$ indicated that the nonrenewal was due to endogenous factors.

TABLE 7 FACTORS WHICH LED TO THE CESSATION/NON-RENEWAL OF SERVICE COMMISSIONS

\begin{tabular}{|c|c|c|c|c|c|c|c|}
\hline \multicolumn{2}{|c|}{$\begin{array}{l}\text { Reasons for the Non-Renewal of Service } \\
\text { Commissions }\end{array}$} & $\begin{array}{c}\text { Coordinators not } \\
\text { integrated in the } \\
\text { LPS }\end{array}$ & $\begin{array}{c}\text { Senior } \\
\text { Managers }\end{array}$ & $\begin{array}{l}\text { Top Public } \\
\text { Servants }\end{array}$ & Total & $\%$ & $\begin{array}{l}\text { Sum } \\
\text { of the } \\
\text { Factors }\end{array}$ \\
\hline \multirow{3}{*}{ 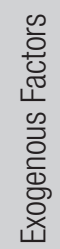 } & $\begin{array}{l}\text { Structural alterations in the organization } \\
\text { (ex.: alterations in the organic structure) }\end{array}$ & 8 & 11 & 98 & 117 & 32.41 & \multirow{3}{*}{54.85} \\
\hline & Change of organizational leadership & 3 & 5 & 34 & 42 & 11.63 & \\
\hline & Change of government & 2 & 13 & 24 & 39 & 10.80 & \\
\hline
\end{tabular}


RAP | (A)Political administration? The public manager's portrait and selection factors

\begin{tabular}{|c|c|c|c|c|c|c|c|}
\hline \multicolumn{2}{|c|}{$\begin{array}{l}\text { Reasons for the Non-Renewal of Service } \\
\text { Commissions }\end{array}$} & $\begin{array}{c}\text { Coordinators not } \\
\text { integrated in the } \\
\text { LPS }\end{array}$ & $\begin{array}{c}\text { Senior } \\
\text { Managers }\end{array}$ & $\begin{array}{l}\text { Top Public } \\
\text { Servants }\end{array}$ & Total & $\%$ & $\begin{array}{l}\text { Sum } \\
\text { of the } \\
\text { Factors }\end{array}$ \\
\hline \multirow{6}{*}{ 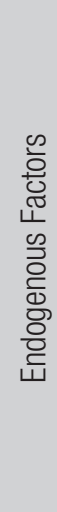 } & $\begin{array}{l}\text { Ideological alterations (ex.: public } \\
\text { policies, guidelines, etc.) }\end{array}$ & 2 & 2 & 8 & 12 & 3.32 & \multirow[t]{5}{*}{45.15} \\
\hline & $\begin{array}{l}\text { Acceptance of other public positions (ex.: } \\
\text { change of organization) }\end{array}$ & 1 & 22 & 51 & 74 & 20.50 & \\
\hline & Personal motives & 6 & 9 & 39 & 54 & 14.96 & \\
\hline & $\begin{array}{l}\text { Divergence in terms of organizational } \\
\text { strategy }\end{array}$ & 1 & 3 & 19 & 23 & 6.37 & \\
\hline & Result of a performance evaluation & 0 & 0 & 0 & 0 & 0.00 & \\
\hline & Total & 23 & 65 & 273 & 361 & 100.00 & 100.00 \\
\hline
\end{tabular}

This does not include other reasons - above all being in the first service commission.

Source: Elaborated by the author.

If we subtract, however, the percentage related to "non-renewal due to the acceptance of other leadership positions" (20.50\%), the endogenous factors fall to $31.10 \%$ and the exogenous factors climb to $68.99 \%$. No leader responded that the service commission was not renewed due to a performance evaluation.

During the professional lives of these leaders, including their current functions, the majority $(68.36 \%)$ said that they had performed in one $(35.79 \%)$ or two $(32.57 \%)$ leadership positions. As the number of distinct positions increases, the number of leaders with these positions decreases. The average number of distinct positions occupied is $2.27-2.95$ for top public servants, 2.14 for senior managers, and 1.82 for coordinators.

\section{TABLE 8 NUMBER OF DIFFERENT LEADERSHIP FUNCTIONS, IN A SERVICE COMMISSION OR EQUIVALENT REGIME, DURING THEIR PROFESSIONAL LIVES, INCLUDING THEIR CURRENT POSITION}

\begin{tabular}{ccccc}
$\begin{array}{c}\mathbf{N}^{0} \text { of different } \\
\text { functions }\end{array}$ & $\begin{array}{c}\text { Coordinators not } \\
\text { integrated with LPS }\end{array}$ & $\begin{array}{c}\text { Senior Managers } \\
1\end{array}$ & $\begin{array}{c}\text { Top Public } \\
\text { Servants }\end{array}$ & Overall Total \\
\hline 2 & $50.00 \%$ & $37.89 \%$ & $19.44 \%$ & $35.79 \%$ \\
\hline 3 & $30.77 \%$ & $33.85 \%$ & $26.39 \%$ & $32.57 \%$ \\
4 & $9.62 \%$ & $12.89 \%$ & $21.53 \%$ & $14.00 \%$ \\
\hline 5 & $3.85 \%$ & $7.68 \%$ & $14.58 \%$ & $8.51 \%$ \\
7 or more & $1.92 \%$ & $3.52 \%$ & $7.64 \%$ & $4.05 \%$ \\
\hline Overall total & $1.92 \%$ & $1.56 \%$ & $2.78 \%$ & $1.76 \%$ \\
\hline
\end{tabular}

Source: Elaborated by the author. 


\section{CONCLUSION}

In Portugal, the reforms of the past few decades have been based essentially on New Public Management, since the practical approach to governance is still not very solid. It has been possible to identify/confirm two components which influence the selection of public administration leaders: political and professional, in line with what has been described in the literature and now demonstrated statistically (Peters, 1996; Peters, 2001b; Downding, 1995; Downs, 1967 as cited in Rocha, 2005b; Goodnow \& Weber, 1959 as cited in Rocha, 2000; Peters, 2001; Wilson, 1887), demonstrating in keeping with other authors (Neuhold et al., 2013) the inexistence of factors which are just neutral and independent of political power and guided exclusively by merit. The political nature of administration (Chevallier, 2002; Kellner, 1981; Mozzicafreddo, 2001; Waldo,1948 as cited in Stillman, 1997) makes the component of politicization also present as one of the identified factors.

In terms of the factors associated with the professional component in the selection of top public servants, which seems to have a greater weight than the political component, the following were identified: knowledge from area of education/specialization; previous experience in public administration; and performing similar functions before as a technical specialist in the same area. In terms of the political component, the 3 main factors are: regularly frequenting the key decision-making circles; political ideology; and party affiliation.

This tendency for professional and political factors to overlap was also verified on the level of senior managers, with the 3 main factors being: the person's behavioral skills, knowledge from area of education/specialization; and skills envisaged in the leadership personnel statute demonstrated in front of a competition jury or a leader before the nomination.

Meanwhile in the political component, the factors are, also in order of importance: political ideology, regularly frequenting the key decision-making circles; and party affiliation.

It was possible to confirm two of the study's hypotheses, and it was not possible to totally confirm the other as will be explained below.

\begin{tabular}{|c|c|c|}
\hline Hypothesis & & Confirmation \\
\hline 1 & $\begin{array}{l}\text { In Portugal between } 2004 \text { and 2011, the factors which influenced the selection of } \\
\text { top public servants were predominantly political. }\end{array}$ & Not verified \\
\hline 2 & $\begin{array}{l}\text { In Portugal between } 2004 \text { and 2011, the factors which influenced the selection of } \\
\text { senior managers were predominantly technical. }\end{array}$ & Verified \\
\hline 3 & $\begin{array}{l}\text { In Portugal between } 2004 \text { and 2011, the factors which influenced the selection of } \\
\text { public administration leaders are distinct depending on whether we are dealing with } \\
\text { top public servants or senior managers. }\end{array}$ & Verified ${ }^{3}$ \\
\hline
\end{tabular}

Source: Elaborated by the author.

Within the context of new governance, it has come to be essential that the profile of public administration leaders includes new skills associated with new roles that they should perform and which undermine the traditional political-administrative dichotomy, with an ideal public administration leader

\footnotetext{
${ }^{3}$ Even though some may be the same, they appear with relatively distinct importance.
} 
being one that can intermediate between the political, administrative and now social-democratic spheres. This triangulation is essential to take advantage of innovation and solve complex problems that face the state, and its leaders need to concentrate on aggregating social preferences, encouraging networking participation, moderating and conciliating interests, building consensus, guaranteeing representation for all those interested and neutrality and independence in proposals, assuring transparency in participative processes, and making information, knowledge, and communication dynamic.

It is believed that this will be the main evolution in the profile of public administration leaders, and that in the case of Portugal, even though this new governance has still not been completely implemented, new initiatives in administrative modernization will soon shape the profiles of public administration leaders to face the challenges of society. Here, the profile of these leaders will be important in terms of their level of selection and education.

Although it is recognized that there is interest in having a better idea of the functioning model of the Recruiting and Selection Commission for Public Administration (CReSAP) in Portuguese public administration, the decision taken in the context of this work has been to highlight the period before its creation for two reasons: the first has to do with the time period that this work required, covering the transitional period between the previous political nomination process and the competitive CReSAP procedures, which have still not been in place for a sufficiently long period of time (greater than a service commission); the second is related to the need to know the dynamics of the relationships between political and administrative actors in the past and to create the CReSAP so that later other studies can compare the impact of its creation.

Complementary studies to this one should be encouraged to make it possible in the future to compare the relationships between politicians and public administration leaders created by the introduction of the CReSAP once it has been consolidated.

In terms of the subject nature of this study, even though it has defined the research problem and examined various hypotheses, relying on quantitative and qualitative methodologies, it is believed that its main contribution has been the clarification of study models that will facilitate a better approach to this problem in the future, in particular creating conditions so that future studies can make evolutionary comparisons of the selection of these leaders and the phenomena of politicization and professionalization, in particular within the context of the implementation of the reforms involved in the creation of the CReSAP.

It may be further concluded that, in line with other countries like France, these public administration leaders lean more to the left than to the right ideologically, as has already been noted in the specialized literature (Rouban, 2007).

Even though the administrative reforms in Portugal have had some impact on administrative structures, this has not been sufficient to make the autonomous management diminish the politicization of the public administration leadership.

This study's contribution to the theoretical development of this area of research is centered on the practical confirmation of the main factors which lead to the selection of these leaders as well as the identification of subfactors and criteria.

This study's results will also make it possible to make future comparisons between countries, comparing factors and indicators of politicization and/or professionalization. It is believed that this study contributes to administration sciences and the knowledge of political-administrative relationships and configurations in the design and implementation of public policies. 


\section{REFERENCES}

Aberbach, J. D. (1988). Image IV Revisited: Executive and Political Roles. Governance, 1, 1-25.

Aberbach, J. D., Putnam, R. D., \& Rockman, B. A. (1981). Bureaucrats and politicians in western democracies. Cambridge, MA: Harvard University Press.

Catlaw, T. J., \& Hu, Q. (2009). Legitimacy and public administration constructing the american bureaucratic fields. American Behavioral Scientist, 53(3), 458-481.

Cattell, R. B. (1966). The scree test for the number of factors. Multivariate Behavioral Research, 1(2), 245-276.

Chevallier, J. (Ed.) (2002). Science administrative. Paris, France: PUF.

Cohen, S., \& Eimicke, W. (2011). Contraction Out. In M. Bevir. (Ed.), The SAGE handbook ofgovernance (1 ed., pp. 576). London, UK: Sage.

Cope, S., Leishman, F., \& Starie, P. (1997). Globalization, new public management and the enabling State. International Journal of Public Sector Management, 10(6), 444-460. Retrieved from https:// doi.org/10.1108/09513559710190816

deLeon, P., \& Vogenbeck, A. M. (2007). Public Policy. In J. Rabin, W. B. Hildreth, \& G. J. Miller. (Eds.), Handbook of Public Administration. Boca Raton, FL: CRC Press Taylor \& Francis.

Denhardt, J., \& Denhardt, R. (2007). The New Public Service: Serving, not Steering. Armonk, NY: M. E. Sharpe.

Dowding, K. M. (1995). Policy-making: civil servants in the cross fire. In K. Dowding. (Ed.), The Civil Service (pp. 108-128). London, UK: Routledge.

Downs, A. (1978). Inside bureaucracy. Boston, MA: Little.

Eymeri, J.-M. (2001). Pouvoir politique et haute administration: une comparaison européenne. Maastricht, The Netherlands: EIPA.

Ferraz, D. (2008a). A selecção de dirigentes públicos no contexto da evolução do Estado e da administração: contributos para uma definição de uma política integrada. (Master Thesis), ISCTE, Lisboa, Portugal.
Ferraz, D. (Ed.). (2008b). A alta direç̧ão pública no contexto da evolução dos modelos Estado e de administração (Cadernos INA, vol. 36). Oeiras, Portugal: INA.

Flinders, M. (2009). The politics of patronage in the United Kingdom: shrinking reach and diluted permeation. Governance, 22(4), 547-570.

Giauque, D., Resenterra, F., \& Siggen, M. (2009). Modernization routes and relations between political and administrative spheres in Switzerland. International Review of Administrative Sciences, 75, 687-713.

Hood, C., \& Lodge, M. (2006). The politics of public service bargains: reward, competency, loyalty-and blame. Oxford, UK: Oxford University Press.

Kaiser, H. F. (1958). The varimax criterion for analytic rotation in factor analysis. Psychometrika, 23(3), 187-200.

Kellner, P. e. L. C.-H. (1981). The civil servants. An inquiry into Britain's ruling class. London, UK: Raven Books.

Mager, P. (1973). COOLEY, W. W. und P. R. LOHNES: Multivariate data analysis. J. Wiley and Sons Inc., New York 1971, 364 S. Biometrische Zeitschrift, 15(4), 294-295.

Mintzberg, H. (1995). In Estrutura e dinâmica das organizações (pp. 345-408). Lisboa, Portugal: Dom Quixote.

Montjoy, R. S., \& Watson, D. J. (1995). A case for reinterpreted dichotomy of politics and administration as a professional standard in councilmanager government. Public Administration Review, 55(3), 231.

Moreira, J. M., \& Alves, A. A. (2010). Gestão pública e teoria das burocracias. Oeiras, Portugal: INA.

Mozzicafreddo, J. (2001). Modernização da administração pública e poder político. In J. Mozzicafreddo \& J. Gomes (Eds.), Administração e política: perspectivas de reforma da administração pública na Europa e nos Estados Unidos. Oeiras, Portugal: Celta Editora.

Mulgan, R. (2007). Truth in Government and the politicization of public service advice. Public Administration, 85(3), 569-586. 
Neuhold, C., Vanhoonacker, S., \& Verhey, L. (Eds.). (2013). Civil servants and politics: a delicate balance. New York, NY: Springer.

Peters, B. G. (1986). The relationship between civil servants and political executives. Glasgow, UK: University of Strathclyde Centre for the Study of Public Policy.

Peters, B. G. (1987). Politicians and bureaucrats in the politics of policy-making. In J. E. Lane (Ed.), Bureaucracy and Public Choice (pp. 256-282). London, UK: Sage.

Peters, B. G. (2001a). The future of governing (2. ed.). Lawrence, KS: University Press of Kansas.

Peters, B. G. (Ed.) (1996). The future of governing: four emerging models. Lawrence, KS: University Press of Kansas.

Peters, B. G. (Ed.) (2001b). The politics of bureaucracy (5 ed.). London, UK: Routledge.

Peters, B. G., \& Pierre, J. (2004). Politicization of the civil service in comparative perspective. London, $\mathrm{UK}$ : Routledge.

Pitschas, R. (2003). Reformas da Administração Pública na União Europeia-Porque necessitamos de mais ética no serviço público. In J. Mozzicafreddo, J. S. Gomes, \& J. S. Batista. (Orgs.), Ética e Administração - Como modernizar os serviços públicos? (pp. 31-46). Oeiras, Portugal: Celta Editora.
Rocha, J. A. O. (2000). Gestão de recursos humanos na administração pública. Lisboa, Portugal: MGI Management Global Information.

Rocha, J. A. O. (2005a). Gestão de recursos humanos na administração pública. Lisboa, Portugal: Escolar Editora.

Rocha, J. A. O. (2005b). Quadro geral da evolução da gestão de recursos humanos na administração pública. Retrieved from http://hdl.handle. net/1822/290

Rocha, J. A. O. (2009). Gestão pública e modernização administrativa. Oeiras, Portugal: INA.

Rouban, L. (2007). Public Management and Politics: Senior Bureaucrats in France. Public Administration, $85,473-502$.

Stillman, R. (1997). American vs. european public administration: does public administration make the modern state or does the state make public administration. Public Administration Review, 57(4), 332-338.

Stoker, G. (2006). Public Value Management: A New Narrative for Networked Governance? The American Review of Public Administration, 36(1), 41-57. Retrieved from https://doi. org/10.1177/0275074005282583

The Northcote-Trevelyan Report. (1954). Public Administration, 32(1), 1-16. Retrieved from https:// doi.org/10.1111/j.1467-9299.1954.tb01719.x

\section{David Ferraz}

\section{https://orcid.org/0000-0002-1470-6464}

Ph.D. in Public Policy; Professor at ISCTE-IUL and ISCSP-UL; General Secretary of the Economic and Social Council and invited investigator Researcher of the Center of Administration and Public Policy (CAPP). E-mail: david.ferraz@gmail.com 